\title{
U10 Infere Artuiter
}

\section{vom

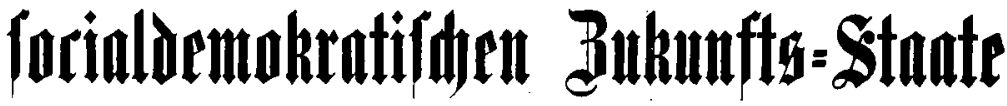

\section{$\mathfrak{j}^{\mathfrak{u}}$ ermarten haben.}

\section{In einem Bmiegefpräđfe}

für J̌ebermant ver îtändid nadgemiefen

port

\section{1.}

Umtsgetidtsrath,

Mitglied des Deutfien Reiahstags und des Preubifhen Ubgearbnetenhaufes.

\section{Breis 30 Mi.}

Bon 25 Exremplaren ah à 25 Bf.

\begin{tabular}{|c|c|c|}
\hline 100 & & $"$ à 15 \\
\hline 300 & & à $121 / 2$ n \\
\hline$" 500$ & & à 10 , \\
\hline " 1000 & " & " \\
\hline
\end{tabular}

Ucberfezungsredit vorbehalten.

Berlin 1895.

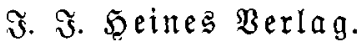


